\title{
Influence of Dissolved Inorganic Carbon and Nitrogen Sources on Growth, Total Lipid Content and Calorific Value of the Freshwater Oleaginous Microalgae Ankistrodesmus falcatus (Corda) Ralfs
}

\author{
Jayanta Talukdar ${ }^{1}$, Mohan Chandra Kalita ${ }^{1}$ and \\ Bhabesh Chandra Goswami ${ }^{2}$ \\ ${ }^{1}$ Department of Biotechnology, Gauhati University, Guwahati - 781014, Assam, India \\ ${ }^{2}$ Department of Chemistry, Gauhati University, Guwahati-781014, Assam, India \\ cross'ref http://dx.doi.org/10.5755/j01.erem.61.3.1423
}

(received in March, 2012, accepted in September, 2012)

\begin{abstract}
Biofuel potentiality of a native strain of freshwater oleaginous microalgae A.falcatus was studied owing to its inherently high lipid content. The influence of media constituents, $\mathrm{pH}$ and nitrogen sources on growth $(\mu)$, total lipid (TL) content and calorific value (CV) was compared in the batch culture. The bold basal medium was superior $\left(\mu=0.498 \mathrm{~d}^{-1}, \mathrm{TL}=43.4 \%\right.$ and $\left.\mathrm{CV}=23.4 \mathrm{kJg}^{-1}\right)$ to BG11 $\left(\mu=0.385 \mathrm{~d}^{-1}, \mathrm{TL}=38.2 \%\right.$ and $\mathrm{CV}=19.2 \mathrm{kJg}^{-1}$ ). Initial culture $\mathrm{pH}<7.0$ and $>9.0$ significantly affected the growth of microalgae. Medium $\mathrm{pH}(\approx 7.0)$ and $\mathrm{NaHCO}_{3}\left(30 \mathrm{mgL}^{-1}\right)$, were found suitable for the optimum growth at the light intensity of $35 \mu \mathrm{mol}$ photons $\mathrm{m}^{-2} \mathrm{~s}^{-1}$, the temperature of $25 \pm 2{ }^{0} \mathrm{C}$ and the photoperiod of 16:8 h light and dark diurnal cycles. $\mathrm{NO}_{3}{ }^{-}$instead of $\mathrm{NH}_{4}{ }^{+}$was preferred in the range of $\mathrm{KNO}_{3}>\mathrm{NaNO}_{3}>\mathrm{NH}_{4} \mathrm{NO}_{3}>$ $\left(\mathrm{NH}_{2}\right)_{2} \mathrm{CO}$ for maximum biomass and lipid production. Maximum biomass, TL and $\mathrm{CV}\left(0.843 \mathrm{gL}^{-1}, 42.7 \%\right.$ and $20.6 \mathrm{kJg}^{-1}$ respectively) were determined in the medium containing $\mathrm{KNO}_{3}(17.6 \mathrm{mM})$. A close linear correlation between an increase in TL and CV was observed $\left(\mathrm{R}^{2}=0.9461\right)$. With the further augmentation of $\mathrm{TL}$ and improved biomass yield the native strain of microalgae A.falcatus could be a potent candidate for biofuel production.
\end{abstract}

Key words: Ankistrodesmus falcatus, biofuel, calorific value, microalgae, oleaginous.

\section{Introduction}

Spectacular global economic development coupled with the increasing population growth and changing life styles since the dawn of the Industrial Revolution have caused ravenous appetite for fossil fuels resulting in a manifold increase in anthropogenic emissions of greenhouse gases (GHGs). The unprecedented rise of anthropogenic GHGs emissions, whose $75 \%$ constitute carbon dioxide $\left(\mathrm{CO}_{2}\right)$, is chiefly responsible for global warming (Ramanathan 1998). As the global energy consumption is raising with increasing demands, an abrupt rise in $\mathrm{CO}_{2}$ and other GHGs is bound to take place, unless there is a replacement of current primary energy resources with a carbon neutral clean energy system. The quest for renewable sources of carbon neutral alternative energy has therefore become the center stage of current energy researches and policies.

Biomass is the only renewable source of alternative energy that can replace fossil fuels in all energy markets - in the production of heat, electricity and fuels for transport. Concerted efforts are now globally underway to harness alternative energy from renewable biomass sources generated via photosynthesis to move towards more sustainable biobased economies, where biomass-derived products substitute petrochemical-derived products (Borowitzka and Moheimani 2011). Development of the first and second generations of biofuel, which are based on different categories of biomass feedstock and downstream processing typically obtained from starch, oil and cellulosic crops, require cultivated land 
and water supplies that can compete with the land use for food production (Hill et al. 2006; Brennan and Owende 2010; Piccolo 2008). Extensive cropping of plants for biofuel production, which will certainly take place with the increasing fuel demand, raises a food vs fuel dilemma and also natural resources demand problems (Walkar 2010; Schenk et al. 2008; Searchinger et al. 2008; Singh et al. 2011). With such limitations of the first and second generation biofuels, microalgae based third and further generations of biofuel have gained an astonishing interest (Campbell 1996; Chisti 2007; Li et al. 2008; Rodolfi et al. 2009; Mata et al. 2010; Spolaore et al. 2006).

Microalgae are considered to represent the only current renewable biomass source to generate biofuel, which are likely to have a much lower adverse effect on the environment and on the world's food supply than conventional biofuel-producing crops. The unique diversity of microalgae and the spectrum of species available for amenability for biofuel production as compared to other advanced biomass feedstock have placed microalgae in the priority list. Various species may be selected to optimize the production of different biofuels. Microalgae biomass can be utilized to produce varieties of fuels, such as liquid fuels and gases, gas-or oil-based biofuels, bioethanol or methanol, biohydrogen and biodiesel (Hill et al. 2006; Brennan and Owende 2010; Walkar 2010; Chisti 2007; Li et al. 2008; Miao and Wu 2004; Pirt et al. 1983; Kosaric and Velikonja 1995; Illman et al. 2000; Banerjee et al. 2002; Pienkos and Darzins 2009; Gong and Jiang 2011; Pokoo-Aikins et al. 2010; Melis and Happe 2001; Clarens et al. 2010). Moreover, microalgae offer a diverse spectrum of valuable products and pollution solutions, such as food, nutritional compounds, omega-3 fatty acids, animal feed, organic fertilizers, biodegradable plastics, recombinant proteins, pigments, medicines, pharmaceuticals, and vaccines (Pulz 2004).

Production of liquid biofuels from microalgae involves to some extent extraction or conversion before the algae can be used as a biofuel. The direct uses of microalgae biomass do not involve such processing and thus minimize the cost. Illman et al. (2000) reported the use of dried powder of microalgae Chlorella as fuel together with a mixture of $85 \%$ cellulose powder and $15 \%$ diesel to run a diesel engine. A high calorific value of microalgae is essential for their use as a fuel, which chiefly depends on the lipid content besides carbohydrate and protein. An increasing calorific value is directly related to an increase in lipid content (Illman et al. 2000).

The economic feasibility of microalgae based biofuel production depends basically on two major factors viz. the cost of commercial scale cultivation (appropriate technology), and the selection of microalgae strain (appropriate strain). High lipid content, faster growth rate, ease of harvest, and dominance in nature possessing an ability to adapt to the prevalent climatic conditions are some of the desirable criteria for choosing the right species for biofuel production (Gong and Jiang 2011). Isolation of native strains from local water bodies can provide the best information regarding the selection of appropriate strain(s) in terms of biomass and lipid productivity, dominant in the native algal flora, and hence they are likely to be the most suitable for being selected as biomass feedstock (Abou-Shanab et al. 2011; Pérez et al. 2004; Odlare et al. 2011). In addition to the species selection, a nutritional requirement for culture optimization is another essential factor that significantly affects the growth rate and the yield of products (Sanchez et al. 2000; Li et al. 2008). Providing optimum conditions some microalgae can double their biomass in less than 24 hours (Chisti 2007). Such high yield and high density biomass is ideal for intensive cultivation and can provide an excellent biomass source of biofuels. Numerous studies have been conducted on enhancement of the lipid content in a number of microalgae by applying various stress condition during cultivation such as nitrogen deprivation (Illman 2000; Sanchez 2000), high light intensity (Khotimchenko and Yakovleva 2005), high salinity (Araujo et al. 2011; Rao et al. 2007), phosphate limitation (Reitan et al. 1994), or co-immobilizing in alginate beads with bacterium Azospirilium brasilense (Lebsky et al. 2001; de-Bashan 2002). Significant increase in lipid contents in microalgae was reported after being subjected to such stress conditions. Oil levels of $20-50 \%$ in dry weight biomass are quite common and some can exceed $80 \%$ (Day et al. 2011). However, stress conditions also have a negative influence on growth resulting in low overall biomass production. Therefore, it is more appropriate to apply stress condition in the later stage of the growth after the initial biomass production (Liu et al. 2008).

The inherently high lipid containing microalgae A.falcatus were previously extensively studied in the biodiesel production under the Aquatic Species Programme, USDOE (Sheehan et al. 1998). A.falcatus was also reported among very high lipid productivities (109 $\left.\mathrm{mg} \mathrm{L}^{-1} \mathrm{~d}^{-1}\right)$ with a high biomass productivity (0.46 $\mathrm{g} \mathrm{L}^{-1} \mathrm{~d}^{-1}$ ) (Griffiths and Harrison 2009). Kilham et al. (1997) reported the changes in biochemical contents and compositions of Affalcatus under various nutritional conditions. They showed increased lipid contents with increasing TGA under phosphorous limited conditions of both nitrogen limitation and non-limited conditions. Our preliminary screening of native oleaginous microalgae resources revealed the ubiquitous nature of A.falcatus strain in the region containing high total lipid content of around $40 \pm 5 \%$ that could be utilized as a potential renewable feedstock of biofuel.

The present study was focused on growth, biomass productivity and total lipid content of a native Indian strain of freshwater microalgae A.falcatus. The principal objectives were: to investigate the influence of medium compositions, added nitrogen sources, dissolved inorganic carbon concentration and $\mathrm{pH}$ on growth with the aim to obtain optimum conditions for an enhanced growth rate and biomass productivity, improved lipid yield 
and higher calorific value under laboratory conditions preceding the mass cultivation.

\section{Methods}

\subsection{Microalgae strain isolation}

A native strain of freshwater Chlorophyta A.falcatus was isolated from the natural water samples collected from wetland Deepor Beel ( Ramsar site), located $\left(26.13^{\circ} \mathrm{N} 91.66^{\circ} \mathrm{E}\right)$ in Guwahati, Assam, India. Isolation of the individual algae was done after several dilutions followed by streaking into an agar plate containing the autoclaved BG11medium (Boussiba and Vonshak 1991) solidified with 1\% agar (w/v) according to Kawai et al. (2005). Petri plates were allowed to stand for 4-7 days under controlled laboratory conditions. Individual algal cells were picked up by means of a sterilized Pasteur pipette and re-inoculated into $10 \mathrm{ml}$ of the sterilized BG11 medium in screw-capped glass vials. Purity of the culture was periodically checked under microscope (LOBAMED, Model: ATC 2000) and by streaking into agar plates. Contamination free culture from other algal species was raised using BG11 medium. Subculture was done after every third week of inoculation.

\subsection{Growth conditions and growth media}

Isolated mono cultures of the tested microalgae were raised and maintained aseptically in the autoclaved BG11medium under controlled laboratory conditions. The $\mathrm{pH}$ of the medium was adjusted to 7.5 with either $1 \mathrm{~N} \mathrm{HCl}$ or $1 \mathrm{~N} \mathrm{KOH}$ solution prior to autoclaving. The growth conditions were: irradiance $35 \mu$ mole photons. $\mathrm{m}^{-2} \mathrm{~s}^{-1}$, temperature $25 \pm 2{ }^{0} \mathrm{C}$ and 16:8 h light and dark diurnal cycles.

\subsection{Effects of medium constituents and initial medium pH on growth}

A triplicate study was conducted for 12 days of culture duration using $100 \mathrm{ml}$ of BG11 and Bold Basal Medium (BBM) (Nichols and Bold 1969) in Erlenmeyer flasks to compare the growth responses of the studied microalgae species. The medium was adjusted to $\mathrm{pH} 7.5$ with either $1 \mathrm{~N} \mathrm{HCl}$ or $1 \mathrm{~N} \mathrm{KOH}$ prior to autoclaving. Various constituents of both media are shown in Table 1.

Growth responses of the microalgae at various initial medium $\mathrm{pH}$ were investigated in a batch mode using the BG11 medium for 7 days of culture duration in order to observe the influence of initial medium $\mathrm{pH}$ on growth as well as dynamic changes of $\mathrm{pH}$ over the culture duration. The medium $\mathrm{pH}$ was adjusted to six levels of initial medium $\mathrm{pH}$ (from 5.0 to 10.0) in an increasing order with either $1 \mathrm{~N} \mathrm{HCl}$ or $1 \mathrm{~N} \mathrm{KOH}$ at the beginning of the experiment prior to autoclaving. The medium $\mathrm{pH}$ was not further adjusted to its initial value during the study period. Dynamic changes of the culture $\mathrm{pH}$ were studied in a batch mode for culture duration of 10 days. The initial culture $\mathrm{pH}$ was adjusted to $\mathrm{pH} 7.5$ prior to autoclaving similarly as stated in the earlier experiment. Changes in the culture medium $\mathrm{pH}$ and an increase in cell numbers over culture duration were recorded after every $24 \mathrm{~h}$ using a standard laboratory $\mathrm{pH}$ meter (L1 120, Elico, India). Studies were conducted in triplicate under similar growth conditions as stated in earlier section.

Table 1. Culture media recipes

\begin{tabular}{|c|c|c||}
\hline \hline Constituents $\mathbf{g L}^{-1} \mathbf{)}$ & BBM & BG11 \\
\hline $\mathrm{NaNO}_{3}$ & 1.0 & 1.5 \\
\hline $\mathrm{CaCl}_{2} .2 \mathrm{H}_{2} \mathrm{O}$ & 0.025 & 0.036 \\
\hline $\mathrm{MgSO}_{4} 7 \mathrm{H}_{2} \mathrm{O}$ & 0.075 & 0.075 \\
\hline $\mathrm{K}_{2} \mathrm{HPO}_{4}$ & 0.075 & 0.4 \\
\hline $\mathrm{NaCl}$ & 0.025 & Nil \\
\hline $\mathrm{EDTA}$ & $\mathrm{Nil}$ & 0.001 \\
\hline $\mathrm{Citric} \mathrm{acid}$ & $\mathrm{Nil}$ & 0.006 \\
\hline $\mathrm{Na}_{2} \mathrm{CO}_{3}$ & $\mathrm{Nil}$ & 0.2 \\
\hline $\mathrm{FeCl}_{3} 6 \mathrm{H}_{2} \mathrm{O}$ & 0.005 & $\mathrm{Nil}$ \\
\hline $\mathrm{NaMoO}_{4}$ & $4.2 \times 10^{-5}$ & $2.1 \times 10^{-5}$ \\
\hline $\mathrm{ZnSO}_{4} 7 \mathrm{H}_{2} \mathrm{O}$ & $4.4 \times 10^{-4}$ & $2.2 \times 10^{-4}$ \\
\hline $\mathrm{MnCl}_{2} 4 \mathrm{H}_{2} \mathrm{O}$ & $3.6 \times 10^{-3}$ & $1.8 \times 10^{-3}$ \\
\hline $\mathrm{CuSO}_{4} 5 \mathrm{H}_{2} \mathrm{O}$ & $1.6 \times 10^{-5}$ & $0.8 \times 10^{-5}$ \\
\hline $\mathrm{H}_{3} \mathrm{BO}_{4}$ & $5.7 \times 10^{-3}$ & $2.8 \times 10^{-3}$ \\
\hline
\end{tabular}

\subsection{Effects of dissolved inorganic carbon (DIC) on growth}

Influence of DIC concentration on the growth responses of the tested microalgae was studied using five levels of sodium bicarbonate $\left(\mathrm{NaHCO}_{3}\right)$ salt concentration $\left(10,30,50,70\right.$ and $\left.90 \mathrm{mg} \mathrm{L}^{-1}\right)$ in BG11 $\left(\mathrm{Na}_{2} \mathrm{CO}_{3}\right.$ was excluded while preparing the $\mathrm{NaHCO}_{3}$ enriched media). Normal BG11 medium was used as the control. Initial $\mathrm{pH}$ of each treatment was adjusted to $\mathrm{pH} 7.5$ before autoclaving. The batch study was conducted in triplicate using $100 \mathrm{ml}$ of the culture medium in $250 \mathrm{ml}$ volume Erlenmeyer flasks, inoculated with $20 \%(\mathrm{v} / \mathrm{v})$ of the exponentially growing culture. Growth conditions were the same as stated in earlier Sections.

\subsection{Effects of added nitrogen (N) sources}

Influence of various $\mathrm{N}$-sources on the growth responses of the strain were studied in the batch culture in triplicate for 21 days. The BG11 medium was modified by substituting sodium nitrate $\left(\mathrm{NaNO}_{3}\right)$ as a regular $\mathrm{N}$-source with equal molar concentration $(17.6 \mathrm{mM})$ of potassium nitrate $\left(\mathrm{KNO}_{3}\right)$, urea $\left(\mathrm{NH}_{2}\right)_{2} \mathrm{CO}$ and ammonium nitrate $\left(\mathrm{NH}_{4} \mathrm{NO}_{3}\right)$, respectively. The other medium constituents and $\mathrm{pH}$ were kept unchanged as those of the normal BG11 medium. For inoculation, $20 \%(\mathrm{v} / \mathrm{v})$ of the two weeks old exponentially growing culture was used as inoculums for each of the treatment. 


\subsection{Growth evaluation}

Growth characteristics were determined from the respective growth curves developed by plotting the observed number of cells (cells $\mathrm{ml}^{-1}$ ) against the time of observations (days). Cell numbers were determined from a direct cell count using Neubour Haemocytometer. Cell density was determined by measuring optical density of the culture at $730 \mathrm{~nm}$ using a Spectrophotometer (SYSTRONICS, Model No.104). For each parameter, the average values were calculated from the data generated from three replicates of each study. Specific growth rate $(\mu)$ and doubling time $\left(\mathrm{T}_{2}\right)$ were calculated by using equations (1) and (2) according to Levasseur et al. (1993).

$$
\begin{aligned}
& \mu=\ln \left(\mathrm{N}_{2} / \mathrm{N}_{1}\right) / \mathrm{t}_{2}-\mathrm{t}_{1} \\
& \mathrm{~T}_{2}=0.6931 / \mu
\end{aligned}
$$

where:

$\mathrm{N}_{1}$ and $\mathrm{N}_{2}-$ cell numbers at time $\mathrm{t}_{1}$ and time $\mathrm{t}_{2}$, respectively.

Biomass was determined as dry cell weight (DCW) and measured gravimetrically. A known volume of the culture was filtered through preweighed and pre-combusted GF/C filter paper. The filtered cell mass was oven dried at $80{ }^{\circ} \mathrm{C}$ for $6 \mathrm{~h}$ until the constant weight; cooled down to the room temperature in desiccators and dry weight of the sample was measured using an analytical balance with precision of $0.1 \mathrm{mg}$. Biomass was expressed in gram DCW per liter $\left(\mathrm{gL}^{-1}\right)$.

\subsection{Determination of total cellular carbohydrate and protein content}

Total cellular carbohydrate and protein content was determined from a known amount of the freeze dried cell biomass harvested at the end of a logarithmic phase of the growth. Protein content was determined according to Lowry et al. (1951) and carbohydrate content was determined according to Hedge et al. (1962).

\subsection{Extraction and estimation of total cellular lipid content}

Total cellular lipid content was determined quantitatively. A known volume of the culture was harvested during a late exponential phase of growth by centrifugation at $4000 \mathrm{rpm}$ for 3-5 minutes, rinsed with $1 \% \mathrm{NaCl}$ solution followed by rinsing with double distilled water twice. The biomass was lyophilized using a freeze-dryer (ALPHA 1-4, Germany) for 36-48 h and kept in a desiccator until its constant weight. Total lipids were extracted from a known amount of the finely grinded lyophilize cell biomass with 2:1 mixture of chloroform $\left(\mathrm{CHCl}_{3}\right)$ and methanol $\left(\mathrm{CH}_{3} \mathrm{OH}\right)$ according to the method of Bligh and Dyer(1959). The residue was re-extracted (2-3 times) with $\mathrm{CHCl}_{3}$. The filtrate was taken in a separating funnel and lipids were obtained in a bottom $\mathrm{CHCl}_{3}$ layer formed upon adding $0.9 \% \mathrm{NaCl}$ and collected in a cleaned pre-weighted glass vial. The solvent was evaporated at $55^{\circ} \mathrm{C}$ in a water bath to near dryness and dried in desiccators under reduced pressure over anhydrous $\mathrm{Na}_{2} \mathrm{SO}_{4}$. The dried lipid extract was measured gravimetrically and expressed in percent $(\%)$ of total lipids per dry cell weight (DCW).

\subsection{Determination of calorific value (CV)}

Calorific value (CV) of studied microalgae was determined using an automatic adiabatic bomb calorimeter (Model: RBC 106/09) according to DIN 51900 T3 (testing of solid and liquid fuels, determination of gross calorific value by a bomb calorimeter and calculation of net calorific value; method with adiabatic jacket). A crucible with a pellet containing $1 \mathrm{~g}$ of dry algal biomass (moisture free) was inserted into the bomb and filled with oxygen (99.99\% purity) under pressure of 30 bars. The bomb was placed in the adiabatic calorimetric equipment filled with water and the sample was ignited (Illman 2000). Calorific value was calculated from the resulting increase in the water temperature using equation (3).

$\mathrm{CV}=\left(\mathrm{W}_{\mathrm{E}} \times \Delta \mathrm{T} / \mathrm{W}_{\mathrm{M}}\right) \times\left(4.18400 \times 10^{-3}\right) \mathrm{kJ} \mathrm{g}^{-1}$

where:

$\mathrm{W}_{\mathrm{E}}$ - enthalpy of water equal to $2568.293 \mathrm{cal} \mathrm{g}$;

$\Delta \mathrm{T}$ - differences in temperature;

$\mathrm{W}_{\mathrm{M}}$ - sample weight.

\subsection{Statistical analysis}

Statistical analysis such as, standard error of means (SE), two way analysis of variance (ANOVA), etc were done using the software GraphPad Prism version: 5.00 .

\section{Results}

\subsection{Effect of medium}

The growth pattern of the native A.falcatus strain in two media, BG11 and BBM are depicted in Fig. $1(\mathrm{~A} \& \mathrm{~B})$. The principal compositional variation was the presence of $40 \mathrm{mM} \mathrm{NaCl}$ in $\mathrm{BBM}$, while the BG11 medium was devoid of any $\mathrm{NaCl}$ in its composition. After an initial lag phase of about 2-3 days, the algae grew exponentially from the $4^{\text {th }}$ day onwards. The exponential growth phase in BBM lasted till the $8^{\text {th }}$ day with the maximum specific growth rate $(\mu)$ of $0.498 \mathrm{~d}^{-1}$ and the least doubling 
time $\left(\mathrm{T}_{2}\right)$ of 1.39 days. On the other hand, the exponential growth phase in the BG11 medium lasted between the $4-6^{\text {th }}$ days with a comparatively slower growth rate $\left(\mu=0.385 \mathrm{~d}^{-1}\right.$ and $\mathrm{T}_{2}=1.8$ days $)$ than that in BBM.

Total cellular lipid, carbohydrate and protein contents were estimated from the biomass at the end of the experiment (12 days of cultivation). Marginal increase in lipid (43.3\%), carbohydrate (13.5\%) and protein $(5.1 \%)$ contents were recorded for the culture grown in the BBM compared to those of the BG11 medium (lipid 38.4\%, carbohydrate $12.5 \%$ and protein $3.1 \%$ ).

\subsection{Effect of initial culture pH on growth}

Growth responses of the studied A.falcatus strain under different initial culture $\mathrm{pH}$ (5.0 to 10.0) are shown in Table 2. The strain was found to grow in a wide spectrum of the initial culture $\mathrm{pH}$, although the growth rates were significantly influenced by the initial culture medium $\mathrm{pH}$ value of $<7.0$ and $>8.0$ ( $\mathrm{P}$ $<0.0001)$ (Fig. 2A). . The maximum growth $(\mu=$ $\left.0.448 \mathrm{~d}^{-1}\right)$ was observed with initial medium $\mathrm{pH} 8.0$ till the $4^{\text {th }}$ day from the day of inoculation, which slightly decreased afterwards producing an increase in total cell numbers of $26.5 \times 10^{5} \mathrm{ml}^{-1}$. Culture medium of $\mathrm{pH}$ 7.0, on the other hand, supported a constant growth of the strain with the highest specific growth rate of $0.445 \mathrm{~d}^{-1}$ producing the maximum cell numbers $\left(27.6 \times 10^{5} \mathrm{ml}^{-1}\right)$ after 7 days of cultivation (Table 2). Otherwise, an increase in cell numbers was the least in the culture grown with initial culture $\mathrm{pH} 10.0$ (5.0 $\left.\times 10^{5} \mathrm{ml}^{-1}\right)$ followed by $\mathrm{pH} 9.0\left(11.2 \times 10^{5} \mathrm{ml}^{-1}\right)$ and pH $5.0\left(12.2 \times 10^{5} \mathrm{ml}^{-1}\right)$. Results have clearly indicated that the initial culture $\mathrm{pH}$ has a significant effect on growth of the studied A.falcatus strain, which favors a neutral or nearly neutral $\mathrm{pH}(\approx \mathrm{pH} 7.0$ - 8.0) to sustain its optimum growth. Growth was retarded with $\mathrm{pH}$ of the medium below $\mathrm{pH} 7.0$ and above $\mathrm{pH}$ 8.0.
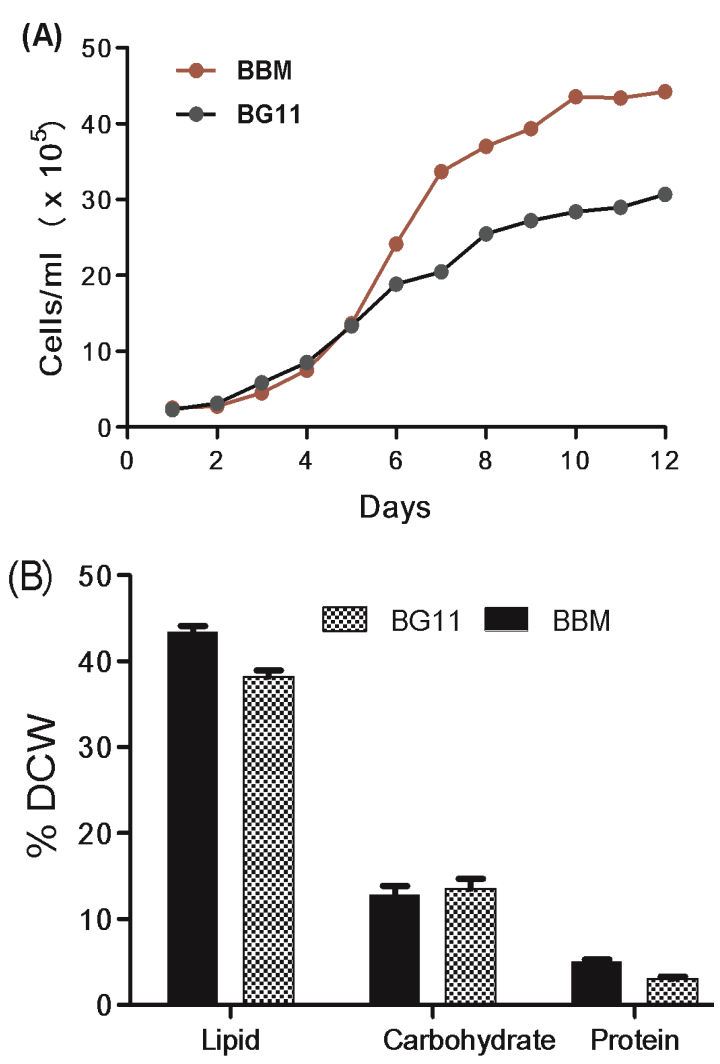

Fig. 1. Effect of medium constituents on (A) growth and (B) biochemical contents of A.falcatus. Error bars represent $S E(n=3)$.

Table 2. Effect of initial pH on growth

\begin{tabular}{|c|c|c|c|c|c|c|}
\hline \multirow{2}{*}{ Days } & \multicolumn{6}{|c|}{ Cells ml ${ }^{-1}\left(\times 10^{5}\right)^{a}$} \\
\hline & pH 5.0 & pH 6.0 & pH 7.0 & pH 8.0 & pH 9.0 & pH 10.0 \\
\hline 1 & $5.2 \pm 0.14$ & $5.3 \pm 0.25$ & $5.4 \pm 0.08$ & $5.3 \pm 0.08$ & $5.2 \pm 0.05$ & $5.3 \pm 0.11$ \\
\hline 2 & $5.6 \pm 0.11$ & $8.0 \pm 0.17$ & $9.1 \pm 0.15$ & $11.1 \pm 0.03$ & $8.5 \pm 0.21$ & $5.3 \pm 0.25$ \\
\hline 3 & $7.4 \pm 0.17$ & $11.3 \pm 0.28$ & $14.8 \pm 0.25$ & $18.5 \pm 0.08$ & $12.7 \pm 0.31$ & $6.0 \pm 0.17$ \\
\hline 4 & $11.3 \pm 0.25$ & $16.2 \pm 0.42$ & $23.1 \pm 0.15$ & $23.3 \pm 0.32$ & $15.3 \pm 0.35$ & $7.7 \pm 0.28$ \\
\hline 5 & $13.9 \pm 0.15$ & $20.7 \pm 0.17$ & $28.1 \pm 0.28$ & $27.2 \pm 0.23$ & $16.2 \pm 0.21$ & $8.8 \pm 0.40$ \\
\hline 6 & $15.2 \pm 0.23$ & $22.6 \pm 0.35$ & $31.1 \pm 0.17$ & $29.6 \pm 0.29$ & $15.8 \pm 0.46$ & $10.1 \pm 0.15$ \\
\hline 7 & $17.9 \pm 0.13$ & $25.2 \pm 0.31$ & $33.1 \pm 0.26$ & $31.8 \pm 0.85$ & $16.4 \pm 0.40$ & $10.3 \pm 0.23$ \\
\hline$\mu \mathrm{d}^{-1}$ & $0.203 \pm 0.002$ & $0.353 \pm 0.01$ & $0.454 \pm 0.02$ & $0.483 \pm 0.01$ & $0.26 \pm 0.003$ & $0.098 \pm 0.01$ \\
\hline $\begin{array}{c}\text { Increase in cells } \\
\mathrm{ml}^{-1}\left(\times 10^{5}\right)\end{array}$ & 12.7 & 19.9 & 27.6 & 26.5 & 11.2 & 5.0 \\
\hline
\end{tabular}



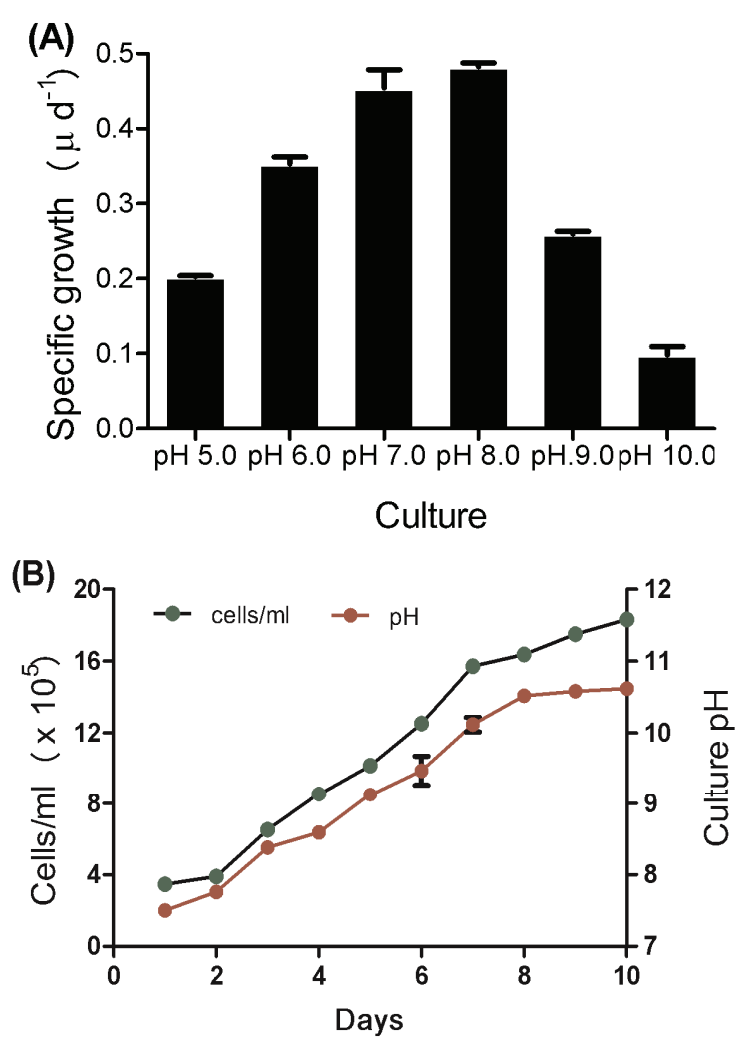

Fig. 2. Effect of initial culture $p H$ on growth of A.falcatus strain (A). Dynamic change of culture $\mathrm{pH}$ and cell abundance during the experiment (B). Error bars represent $S E(n=3)$

\subsection{Dynamic change in culture $\mathrm{pH}$ over culture duration}

A dynamic change of the culture $\mathrm{pH}$ in a studied batch mode, where the culture $\mathrm{pH}$ was not controlled intermediately is shown in Fig. 2(B). Irrespective of the initial culture $\mathrm{pH}(7.5)$ at the time of inoculation, the $\mathrm{pH}$ of the culture medium was found to increase gradually, reaching over 10.0 after 7 days of the culture period and then the increase in culture $\mathrm{pH}$ was nearly steady till the terminal $10^{\text {th }}$ day of the experiment (Fig. 2B). As seen from Fig 2(B) an increase in the culture $\mathrm{pH}$ as high as over 10.0 (day 7 onwards after inoculation) retarded the further growth and increase in cell numbers of the studied A.falcatus strain under the tested conditions.

\subsection{Effect of dissolved inorganic carbon (DIC) on growth}

DIC concentrations in terms of $\mathrm{NaHCO}_{3}$ at various concentrations were found to influence growth of the studied A.falcatus strain (Fig. 3). $\mathrm{NaHCO}_{3}$ at a concentration of $30 \mathrm{mg} \mathrm{L}^{-1}$ significantly $(\mathrm{P}<0.001)$ stimulated the growth rate with the maximum specific growth rate of $0.368 \mathrm{~d}^{-1}$. However, the concentration of bicarbonate salt beyond $50 \mathrm{mg} \mathrm{L}^{-}$ ${ }^{1}$ retarded the growth rate. The maximum net increase in cell numbers $26.5 \times 10^{5} \mathrm{ml}^{-1}$ was recorded in the medium supplemented with $30 \mathrm{mg} \mathrm{L}^{-1}$ of $\mathrm{NaHCO}_{3}$, followed by $50 \mathrm{mg} \mathrm{L}^{-1}$ of $\mathrm{NaHCO}_{3}\left(21.5 \times 10^{5} \mathrm{ml}^{-1}\right)$ compared to $17.3 \times 10^{5} \mathrm{ml}^{-1}$ at the control on the terminal experiment day. No significant $(\mathrm{P}>0.05)$ differences were found in other treatment with the control.

\subsection{Effect of added N-sources on biomass and lipid productivity}

Growth of the studied A.falcatus strain was influenced by the forms of $\mathrm{N}$-sources contained in the culture medium, both in terms of biomass and lipid yield (Fig. 4A-B). Among the tested N-sources, $\mathrm{KNO}_{3}$ was found to be the most suitable to grow the studied microalgae strain for biomass production (Fig. 4A). The strain yielded maximum $0.843 \mathrm{~g} \mathrm{~L}^{-1}$ biomass (DCW) containing $42.76 \%$ of total lipid content after 21 days of the culture period in the medium fed with $\mathrm{KNO}_{3}$. The highest biomass and lipid productivity of $0.038 \mathrm{~g} \mathrm{~L}^{-1} \mathrm{~d}^{-1}$ and $0.019 \mathrm{~g} \mathrm{~L}^{-1} \mathrm{~d}^{-1}$, respectively, was also recorded in the culture fed with $\mathrm{KNO}_{3}$; whereas both biomass and lipid productivity were the least in the cultures fed with urea $\left(0.007 \mathrm{~g} \mathrm{~L}^{-1} \mathrm{~d}^{-1}\right.$ and $0.004 \mathrm{~g}$ $\mathrm{L}^{-1} \mathrm{~d}^{-1}$, respectively) (Fig. 4B). The culture fed with $\mathrm{NaNO}_{3}$ produced higher lipid content $(41.3 \%)$ than that of $\mathrm{NH}_{4} \mathrm{NO}_{3}(37.7 \%)$, although the total biomass yield did not significantly differ (Fig. 4A). Based on the results revealed from our studies, $\mathrm{KNO}_{3}$ was found to be the most suitable $\mathrm{N}$-source for growing the studied A.falcatus strain considering its both high lipid and biomass productivity.

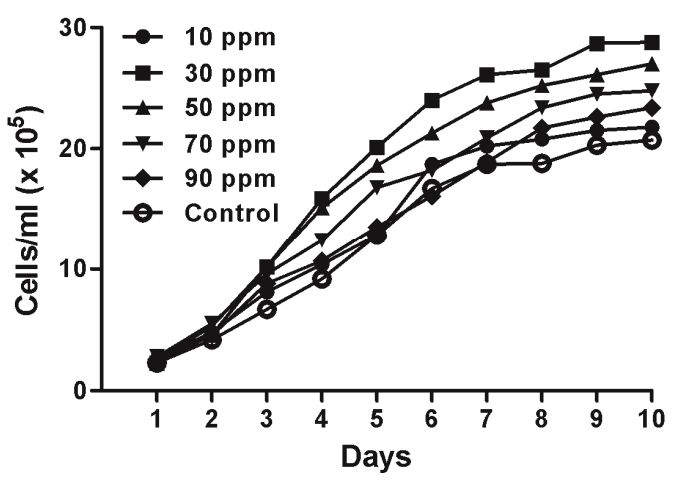

Fig.3. Effect of different concentrations of DIC on growth of A.falcatus strain.

\subsection{Calorific value (CV)}

The calorific value of biomass yield of the studied A.falcatus strain was found to vary with culture media compositions that directly influence the total lipid content of the biomass (Table 3). A.falcatus grown in the BG11 medium for a cultivation period of 12 days containing lipid $38.2 \%$ resulted in a calorific value $19.2 \mathrm{kJg}^{-1}$. Biomass produced in BBM for the same cultivation period containing a lipid content of $43.4 \%$ revealed an increased calorific value $23.4 \mathrm{kJg}^{-1}$. The lowest calorific value $10.46 \mathrm{kJg}^{-1}$ was determined in biomass containing the least lipid content (23.16\%) of 
cultures grown in urea, while the biomass produced in $\mathrm{KNO}_{3}$ supplemented culture containing the maximum lipid content $(42.76 \%)$ revealed the highest calorific value $\left(20.56 \mathrm{kJg}^{-1}\right)$.
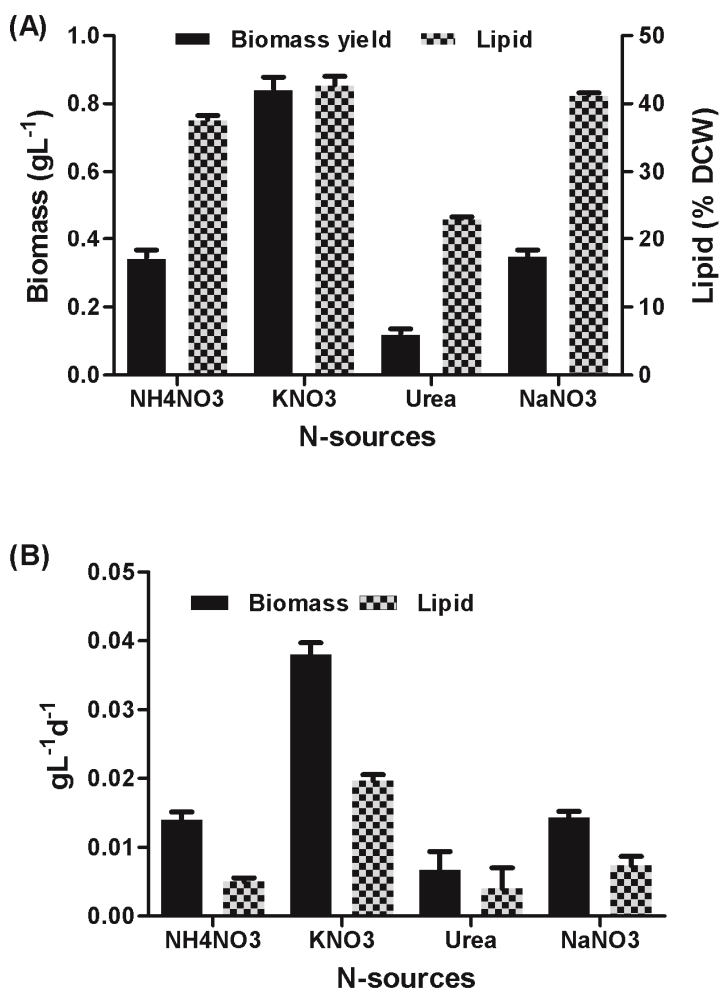

Fig.4. Effect of added nitrogen sources on biomass and lipid production $(A)$ and productivity (B) of A.falcatus strain. Error bars represent $S E(n=3)$.

Table 3. Comparison of calorific values of biomass under different treatments

\begin{tabular}{|l|l|l||}
\hline Treatments & a Lipid (\% DCW) & $\begin{array}{l}\text { a Calorific value } \\
\left(\mathbf{k J g}^{-\mathbf{1}}\right)\end{array}$ \\
\hline Medium & & \\
\hline BG11 & $38.20 \pm 0.737$ & $19.20 \pm 0.099$ \\
\hline BBM & $43.40 \pm 0.700$ & $23.43 \pm 0.120$ \\
\hline $\mathbf{c}$ N-sources & & \\
\hline $\mathrm{KNO}_{3}$ & $42.76 \pm 1.255$ & $20.56 \pm 0.433$ \\
\hline $\mathrm{NaNO}_{3}$ & $41.31 \pm 0.289$ & $20.06 \pm 0.318$ \\
\hline $\mathrm{NH}_{4} \mathrm{NO}_{3}$ & $37.70 \pm 0.586$ & $17.43 \pm 0.120$ \\
\hline Urea & $23.16 \pm 0.203$ & $10.46 \pm 0.145$ \\
\hline
\end{tabular}

${ }^{a}$ values are mean of three independent values; ${ }^{b}$ values are mean of five independent values; ${ }^{c}$ equal molar concentration of $17.6 \mathrm{mM}$ was used for all $N$-sources in BG11 medium. ' \pm ' represents standard error of means

\section{Discussion}

The present studies on native strain of A.falcatus have revealed a high lipid content possessing potentialities to be used as renewable biomass feedstock for biofuel production. Our results have demonstrated that the strain favors BBM over BG11 for growth. In BBM the highest cell numbers (44.2 $\mathrm{x}$ $10^{5} \mathrm{ml}^{-1}$ ) were recorded after 12 days of cultivation with an initial cell number of $2.5 \times 10^{5} \mathrm{ml}^{-1}$ at the time of inoculation. Marginal increase in biochemical contents such as lipid (43.4\%), carbohydrate (12.8\%) and protein $(5.0 \%)$ at dry weight of biomass were also recorded in the cultures grown in BBM while in BG11 medium they were: lipid 38.2\%, carbohydrate $13.5 \%$ and protein $3.0 \%$. The growth stimulating activity of the BBM might be attributed to the presence of a low level of $\mathrm{NaCl}\left(0.025 \mathrm{~g} \mathrm{~L}^{-1}\right)$ in its constituents. Fodorpataki and Bartha (2004) also reported similar observations of such marginal increased in biochemical contents due to $\mathrm{NaCl}$ induced changes in growth conditions. BG11 medium on the other hand does not contain any $\mathrm{NaCl}$. The results were in parity with an earlier report on A.falcatus strain (Kalita et al. 2011). Similar results on enhanced growth in BBM were also reported in Haematococcus pluvialis (Dominguez-Bocanegra et al. 2004; Imamoglu et al. 2009).

Freely available $\mathrm{CO}_{2}$ and $\mathrm{OH}$ flux of the medium were reported to influence the nitrate uptake of Ankistrodesmus species (Eisele and Ullrich 1997) and growth of green algae species (Gardner et al. 2011). Medium $\mathrm{pH}$ is supposed to act mainly at the plasmalemma since $\mathrm{pH}$ within the cell and its compartments can be regarded as fairly stable. In the absence of $\mathrm{CO}_{2}$, nitrate uptake, and thereby nitrate reduction in Ankistrodesmus were reported to be moderately inhibited, which is strongly $\mathrm{pH}$ dependent. Optimal uptake was reported in between $\mathrm{pH} 8.0$ and about 9.0 (Eisele and Ullrich 1997). Our experimental results from the experiment on influence of initial culture $\mathrm{pH}$ have indicated that the native strain of A.falcatus can grow in a wide range of culture $\mathrm{pH}$ (5.0 - 10.0); however, its growth rate was significantly retarded in both acidic $(<\mathrm{pH} 7.0)$ and alkaline medium $(>\mathrm{pH}$ 9.0). The least number of cells (10.3 $\mathrm{ml}^{-1} \times 10^{5}$ ) was determined in the culture grown with initial $\mathrm{pH}$ 10.0. Culture medium $\mathrm{pH}$ between 7.0 and 9.0 was found to be suitable for growing the studied microalgae strain. The results were in accordance with the findings of Eisele and Ullrich (1997) in A.braunii. They further reported that at $\mathrm{pH} 8.2$, the nitrate uptake was more rapid and almost the entire nitrate taken up was released as ammonia in the absence of $\mathrm{CO}_{2}$, which might be the reason for an abrupt rise in medium alkalinity at the later stage of growth while no external $\mathrm{CO}_{2}$ was supplied. Similar results were also found in our study, where a significant rise in the medium $\mathrm{pH}(<10.0)$ was observed at the terminal day of the experiment. Such increase in culture $\mathrm{pH}$ significantly retarded further growth of the microalgae strain in the studied batch mode. An intermediate $\mathrm{pH}$ control mechanism is therefore essential in addition to nutrient addition for supporting continuous growth of the strain.

$\mathrm{CO}_{2}$ is known to be one of the most important nutrients along with other essential minerals and optimum light condition for growing microalgae 
photoautrophically. To sustain a stable growth and higher biomass production, $\mathrm{CO}_{2}$ must be added into the culture medium from external sources. In this respect, many researchers (Powell et al. 2009) reported supply of pure $\mathrm{CO}_{2}$ as a mixture of air plus $\mathrm{CO}_{2}$ at different ratios. However, due to very low solubility of $\mathrm{CO}_{2}$ in water $\left(1.45 \mathrm{~g} \mathrm{~L}^{-1}\right.$ at $25{ }^{0} \mathrm{C}, 100$ $\mathrm{kPa}$ ) (Wiebe et al. 1940), the majority of carbon dioxide tends to be lost in the air. Moreover, feasibility of appropriate technology, easy availability, and energy intensiveness hinder practical applicability of the technology. Alternatively, bicarbonate salts such as $\mathrm{NaHCO}_{3}$ are highly soluble in water, which can serve as a better source of $\mathrm{CO}_{2}$ for growing microalgae with minimum efforts. When $\mathrm{NaHCO}_{3}$ dissolves in water, it dissociates to produce $\mathrm{HCO}_{3}{ }^{-}$ions that serve for microalgae as readily available dissolved inorganic carbon. However, the optimal upper limit of $\mathrm{NaHCO}_{3}$ concentrations in the growth medium vary accordingly with varying microalgae species/strains (Gardner et al. 2011). Our results indicated that the medium containing $30 \mathrm{mg} \mathrm{L}^{-}$ ${ }^{1}$ of $\mathrm{NaHCO}_{3}$ stimulated the growth of the studied A.falcatus strain. The strain showed its best performance in the BG11 medium supplemented with $30 \mathrm{mg} \mathrm{L}^{-1}$ of $\mathrm{NaHCO}_{3}$ with its highest specific growth $\left(\mu=0.368 \mathrm{~d}^{-1}\right)$ and a maximum increase in cell numbers $\left(26.5 \times 10^{5} \mathrm{ml}^{-1}\right)$ in comparison to the control BG11 medium $\left(\mu=0.278 \mathrm{~d}^{-1} ; 17.3 \times 10^{5} \mathrm{ml}^{-1}\right)$. At higher concentrations of $\mathrm{NaHCO}_{3}$ (beyond $30 \mathrm{mg} \mathrm{L}$ ${ }^{1}$ ), the growth was retarded. Gardener et al. (2011) also reported similar observations in Scenedesmus sp strain WC-1 and Phaeodatylum tricornutum strain Pt1 .

Nitrogen, an essential component of protein and other constituents of protoplasm, is a major nutrient affecting the productivity of microalgae. Microalgae are known to be capable of utilizing various forms of nitrogenous sources $(\mathrm{N})$ both a dissolved form of inorganic nitrogen (DIN) and a dissolved form of organic nitrogen (DON). Flynn and Butler (1986) reviewed the utilization of various forms of N-sources in marine microalgae. Selection of a suitable N-source for growing microalgae is another essential criterion for mass production, though the preferences for utilization vary from species to species (Tepe et al. 2006). In our studies, the native A.falcatus strain was found to favor nitrates $\left(\mathrm{NO}_{3}^{-}\right)$over other forms of $\mathrm{N}$ source for suitable growth. Lipid contents were also recorded higher in the cultures grown in the medium containing $\mathrm{NO}_{3}{ }^{-}$salts of potassium $(\mathrm{K})$, sodium $(\mathrm{Na})$ and ammonium $\left(\mathrm{NH}_{4}{ }^{+}\right)$than in the medium containing urea $\left(\left(\mathrm{NH}_{2}\right)_{2} \mathrm{CO}\right)$ as the sole $\mathrm{N}$-source. The results were in parity with similar observations reported by Chen et al. (2011) in green microalgae Dunaliella tertiolecta. The studied A.falcatus strain revealed the highest biomass $\left(0.843 \mathrm{~g} \mathrm{~L}^{-1} \mathrm{DCW}\right)$ and lipid (42.76\% DCW) contents in the medium fed with $\mathrm{KNO}_{3}(17.6$ $\mathrm{mM})$. Cultures fed with equal molar concentrations of $\mathrm{NH}_{4} \mathrm{NO}_{3}$ and $\mathrm{NaNO}_{3}$ did not demonstrate any significant differences in total biomass production (0.35 $\mathrm{g} \mathrm{L}^{-1}$ and $0.34 \mathrm{~g} \mathrm{~L}^{-1}$ respectively), while total lipid content was found to be higher in $\mathrm{NaNO}_{3}$ $(41.31 \% \mathrm{DCW})$ than that in $\mathrm{NH}_{4} \mathrm{NO}_{3}(37.7 \% \mathrm{DCW})$. Urea was found to be the least favored $\mathrm{N}$-source for growing the studied microalge strain. The results were in accordance with the observations of Tepe et al. (2006) in S.acuminatus that inorganic N-sources are superior to organic N-sources. Organic N-sources need to be mineralized prior to be utilized by microalgae. Similar observation was also reported for Scenedesmus sp. LX1 (Xin et al. 2010), and Chlorella protothecoids (Shen et al. 2010). The order of preferences of different nitrogen sources of the studied A.falcatus strain was $\mathrm{NO}_{3}-\mathrm{N}>\mathrm{NH}_{4}-\mathrm{N}>$ Urea. However, we strongly feel that more studies are needed to be carried out to find the optimum Nconcentration; a much cheaper and better N-source in order to be utilized for mass cultivation of the native A.falcatus strain.

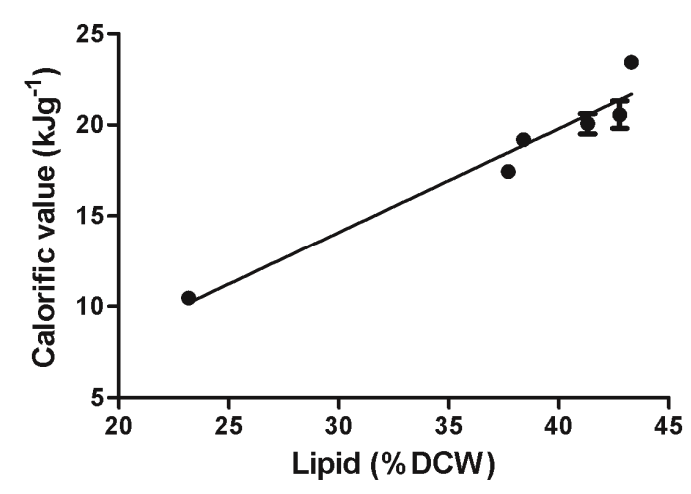

Fig. 5. Co-relation between increased lipid content and calorific value of A.falcatus strain; a close relationship of increasing calorific value with an increase of the total lipid content was observed $\left(R^{2}=0.9461\right)$. SE were calculated from the mean, $n=3$.

The cell biomass grown in normal BG11 medium has revealed calorific value in between 19.2 $-20.6 \mathrm{kJg}^{-1}$ (Table 3), which is in a close agreement with Illman et al. (2000). The principal contribution to the calorific value of cell biomass comes from its total cellular carbohydrate, protein and lipid content (Illman et al. 2000; Scragg et al. 2002; 2003). Microalgae grown under normal conditions were reported to have calorific values between $18-21 \mathrm{kJg}^{-}$ 1 , which is much lower than the calorific value of diesel (42 $\mathrm{kJg}^{-1}$ ) (Illman et al. 2000). However, improved lipid content and thereby improved calorific values were also reported (Illman et al. 2000; Shen et al. 2010), which is also evident from our results (Table 3 and Fig. 5). The tested A. falcatus strain grown in BBM yielded an increased level of lipid content $(43.4 \%)$ and revealed an increased calorific value $\left(23.4 \mathrm{kJg}^{-1}\right)$. Similar results were also reported by Ilmann et al. (2000) in Chlorella vulgaris and C.emersonii. The studied A. falcatus strain achieved a higher biomass yield $\left(0.843 \mathrm{~g} \mathrm{~L}^{-1}\right)$ and productivity $\left(0.038 \mathrm{~g} \mathrm{~L}^{-1} \mathrm{~d}^{-1}\right)$ in BG11 medium fed with $\mathrm{KNO}_{3}$. The 
lipid content $(42.76 \%)$ and productivity $\left(0.019 \mathrm{gL}^{-1} \mathrm{~d}^{-}\right.$ $\left.{ }^{1}\right)$ were also higher in the $\mathrm{KNO}_{3}$ supplemented BG11 medium compared to the cultures fed with other $\mathrm{N}$ sources resulting in an increased calorific value of $20.56 \mathrm{kJg}^{-1}$ (Table 3, Fig. 4(A-B). A close relationship $\left(\mathrm{R}^{2}=0.9461\right)$ between the increasing lipid content and calorific value of A.falcatus was observed (Fig. 5). It is envisaged that microalgae biomass should be used as renewable biofuel for electricity generation using static diesel engines (Illman et al. 2000; Scragg et al. 2003) for which large microalgae biomass production with high productivity and high lipid content must be maintained.

Potential benefits of microalgae cultivation are enormous, and research into algae production using wastewater and power station emissions are inviting a highly prioritized proposition in sustainable and economic development. The ability to expand algal oil harvests depends mostly on: (a) isolation of new strains of algae that produce large amounts of desirable lipids, and (b) identification of environmental conditions that promote rapid growth of the oil-producing algae. Results of our present investigation have revealed the potentialities of the native microalgae strain $A$. falcatus to be utilized as a renewable biomass feedstock of biofuels. Our experimental results may be helpful towards a largescale algae cultivation of the studied microalgae strain, which could be potentially used for sustainable biofuel production.

\section{Acknowledgment}

Partial financial support from the Defence Research Laboratory, Tezpur, Assam, DRDO, the Ministry of Defence, Govt. of India is gratefully acknowledged. Valuable suggestions from the reviewers are appreciated.

\section{References}

ABOU-SHANAB R. A. I., HWANG J. H., CHO Y., MIN B., JEON B. H. Characterization of microalgal species isolated from fresh water bodies as a potential source for biodiesel production. Applied Energy, 2011, Vol. 88, pp. 3300-6. http://dx.doi.org/10.1016/j.apenergy.2011.01.060

ARAUJO G. S., MATOS L. J. B. L., GONCALVES L. R. B., FERNANDES F. A. N. and FARIAS V. R. L. (2011), Bioprospecting for oil producing microalgal strains: evaluation of oil and biomass production for ten microalgal strains. Bioresource Technology, 2011, Vol. 102, pp. 52485250. http://dx.doi.org/10.1016/j.biortech.2011.01.089

BANERJEE A., SHARMA R., CHISTI Y. and BENERJEE, U. C. Botryococcus braunii: A renewable source of hydrocarbons and other chemicals. Critical Reviews Biotechnology, 2002, Vol. 22, pp. 245-279. http://dx.doi.org/10.1080/07388550290789513

BLIGH E. G. and DYER W. J. A rapid method of total lipid extraction and purification. Canadian Journal of Biochemistry Physiology, 1959, Vol. 37, pp. 911-917. http://dx.doi.org/10.1139/o59-099
BOROWITZKA M. A. and MOHEIMANI N. R. Sustainable biofuels from algae. Mitigation and Adaptation Strategies for Global Change, 2011. doi:10.1007/S11027010-9271-9 http://dx.doi.org/10.1007/s11027-010-9271-9

BOUSSIBA S. and VONSHAK A. Astaxanthin accumulation in the green algae Haematococcus pluvialis. Plant and Cell Physiology, 1991, Vol. 32, No.7, pp. $1077-$ 1082.

BRENNAN L. and OWENDE P. Biofuels from microalgae - A review of technologies for production, processing, and extractions of biofuels and co-products. Renewable and Sustainable Energy Reviews, 2010, Vol. 14, pp. 557-577. http://dx.doi.org/10.1016/j.rser.2009.10.009

CAMPBELL C. J. The status of world oil depletion at the end of 1995. Energy Exploration and Exploitation, 1996, Vol. 14, No.1, pp. 63-81.

CHEN M., TANG H., MA H., HOLLAND T. C., SIMON NG K. Y. and SALLY S. O. Effect of nutrients on growth and lipid accumulation in the green algae Dunaliella tertiolecta. Bioresource Technology, 2011, Vol. 102, pp. 1649-1655. http://dx.doi.org/10.1016/j.biortech.2010.09.062

CHISTI Y. Biodiesel from microalgae. Biotechnology Advances, 2007, Vol. 25, pp. 294-306. http://dx.doi.org/10.1016/j.biotechadv.2007.02.001

CLARENS A. F., RESURRECCION E. P., WHITE M. A. and COLOSI L. M. Environmental Life Cycle Comparison of Algae to Other Bioenergy Feedstocks. Environmental Science and Technology, 2010, Vol. 44, pp. 1813-1819. http://dx.doi.org/10.1021/es902838n

DAY J. G., SLOCOMBE S. P. and STANLEY M. S. (2011), Overcoming biological constraints to enable the exploitation of microalgae for biofuels. Bioresource Technology, 2011 (in press). http://dx.doi.org/10.1016/j.biortech.2011.05.033

DE-BASHAN L. E., BASHAN Y., MORENO M., LEBSKY V. K. and BUSTILLOS J. J. Increased pigment and lipid content, lipid variety, and cell and population size of the microalgae Chlorella spp. when co-immobilized in alginate beads with the microalgae-growth- promoting bacterium Azospirillum brasilense. Canadian Journal of Microbiology, 2002, Vol. 48, pp. 514-521. http://dx.doi.org/10.1139/w02-051

DOMINGUEZ-BOCANEGRA A. R., LEGARRETA I. G., JERONIMO F. M. and CAMPOCOSIO A. T. Influence of environmental and nutritional factors in the production of astaxanthin from Haematococcus pluvialis. Bioresource Technology, 2004, Vol. 92, pp. 209-214. http://dx.doi.org/10.1016/j.biortech.2003.04.001

EISELE R. and ULLRICH W. Effect of Glucose and $\mathrm{CO}_{2}$ on Nitrate Uptake and Coupled $\mathrm{OH}^{-}$Flux in Ankistrodesmus braunii. Plant Physiology, 1997, Vol. 59, pp. 18-21. http://dx.doi.org/10.1104/pp.59.1.18

FLYNN K. J. and BUTLER I. Nitrogen sources for the growth of marine microalgae - Role of dissolved free aminoacids. Marine Ecology Progress Series, 1986, Vol. 34, pp. 281-304. http://dx.doi.org/10.3354/meps034281

FODORPATAKI L. and BARTHA C. Salt stress tolerance of a freshwater green alga under different photon flux densities. Sludia Universities Babes-Bolyai, Biologia, 2004, Vol. XLIX, No.2, pp. 85-93.

GARDNER R. D., COOKSEY K. E., MUS F., MACUR R., MOLL K., EUSTANCE E., CARLSON R. P., GERLACH R., FIELDS M. W. and PEYTON B. M. Use of sodium bicarbonate to stimulate triacylglycerol accumulation in the chlorophyte Scenedesmus sp. and the diatom Phaeodactylum tricornutum. Journal of Applied Phycology, 2012 (in press). http://dx.doi.org/10.1007/s10811-011-9782-0 
GARDNER R., PETERS P., PEYTON B., COOKSEY K. Medium $\mathrm{pH}$ and nitrate concentration effects on accumulation of triacylglycerol in two members of the Chlorophyta. Journal of Applied Phycology, 2011, Vol. 26, pp. 1005-1016. http://dx.doi.org/10.1007/s10811-010-96334

GONG Y. and JIANG M. Biodiesel production with microalgae as feedstock: from strains to biodiesel. Biotechnology Letters, 2011, Vol. 33, pp. 1269-1284. http://dx.doi.org/10.1007/s10529-011-0574-z

GRIFFITHS M. J. and HARRISON S. T. L. Lipid productivity as a key characteristic for choosing algal species for biodiesel production. Journal of Applied Phycology, 2009, Vol. 21, pp. 493-507. http://dx.doi.org/10.1007/s10811-008-9392-7

HEDGE J. E. and HOFREITER B. T. 1962. Methods of estimating starch and carbohydrate. In: Whistler R. L. and Be Miller J. N. (eds.): Carbohydrate chemistry, $17^{\text {th }}$ Edition, Academic Press, New York, 163-201 pp.

HILL J., NELSON E., TILMAN D., POLASKY S. and TIFFANY D. Environmental, economic, and energetic costs and benefits of biodiesel and bioethanol fuels. Proceedings of the National Academy of Sciences, 2006, Vol. $30, \quad$ pp. 11206-11210 http://dx.doi.org/10.1073/pnas.0604600103

HU Q., MILTON S. M., JARVIS E., GHIRARDI M., POSEWITZ M., SEIBERT $M$. and DARZINS A. Microalgal triacylglycerols as feedstocks for biofuel production: perspectives and advances. Plant Journal, 2008, Vol. 54, pp. 621-639. http://dx.doi.org/10.1111/j.1365313X.2008.03492.X

ILLMAN A. M., SCRAGG A. H. and SHALES S. W. Increase in Chlorella strains calorific values when grown in low nitrogen medium. Enzyme and Microbial Technology, 2000, Vol. 27, pp. 631-635. http://dx.doi.org/10.1016/S0141-0229(00)00266-0

IMAMOGLU E., DALAY M. C. and SUKAN F. V. Influences of different stress media and high light intensities on accumulation of astaxanthin in the green alga Haematococcus pluvialis. New Biotechnology, 2009, Vol. 26, pp http://dx.doi.org/10.1016/j.nbt.2009.08.007

KALITA N., BARUAH G., DEV GOSWAMI R. C., TALUKDAR J. and KALITA M. C. Ankistrodesmus falcatus: A promising candidate for lipid production, its biochemical analysis and strategies to enhance lipid productivity. Journal of Microbiology and Biotechnology Research, 2011, Vol. 1, No. 4, pp. 148-157.

KAWAI H., MOTOMURA T. and OKUDA K. 2005. Isolation and purification techniques for microalgae. In: Anderson R. A. (ed.): Algal culturing techniques, Elsevier Academic Press, Burlington, USA, 133-144 pp.

KILHAM S. S., KREEGER D. A., GOULDEN C. E. and LYNN S. G. Effects of nutrient limitation on biochemical constituents of Ankistrodesmus falcatus. Freshwater Biology, 1997, Vol. 38, pp. 591-596. http://dx.doi.org/10.1046/j.1365-2427.1997.00231.x

KHOTIMCHENKO S. V. and YAKOVLEVA I. M. (2005), Lipid composition of the red alga Tichocarpus crinitus exposed to different levels of photon irradiance. Phytochemistry, 2005, Vol. 66, pp. 73-79. http://dx.doi.org/10.1016/j.phytochem.2004.10.024

KOSARIC N. and VELIKONJA J. (1995), Liquid and gaseous fuels from biotechnology: challenges and opportunities. FEMS Microbiology Reviews, 1995, Vol. 16, pp. $\quad 111-142$. http://dx.doi.org/10.1111/j.15746976.1995.tb00161.x

LEBSKY V. K., GONZALEZ-BASHAN L. E. and BASHAN Y. Ultrastructure of coimmobilization of the microalga Chlorella vulgaris with the plant growthpromoting bacterium Azospirillum brasilense and with its natural associative bacterium Phyllobacterium myrsinacearum in alginate beads. Canadian Journal of Microbiology, 2001, Vol. 47, pp. 1-8.

LEVASSEUR M. P., THOMSON A. and HARRISON P. J. Physiological acclimation of marine phytoplankton to different nitrogen sources. Journal of Phycology, 1993, Vol. 29, pp. 587-595. http://dx.doi.org/10.1111/j.0022-3646.1993.00587.x

LI Q., DU W. and LIU D. Perspectives of microbial oils for biodiesel production. Applied Microbiology Biotechnology, 2008, Vol. 80, pp. 749-756. http://dx.doi.org/10.1007/s00253-008-1625-9

LI Y., HORSMAN M., WANG B., WU N. and CHRISTOPHER Q. L. Effects of nitrogen sources on cell growth and lipid accumulation of green alga Neochloris oleoabundans. Applied Microbiology Biotechnology, 2008, Vol. 81, pp. 629-636. http://dx.doi.org/10.1007/s00253008-1681-1

LIU Y., RUAN R., and KONG Q. Mass culture of high oil content microalgae on wastewater and power plant flue gases. Chinese Journal Bioprocess Engineering, 2008, Vol. 3, pp. 29-33.

LOWRY O. H., ROSEBROUGH N. J., FARR A. L. and RANDALL R. J. Protein measurement with the folin phenol reagent. Journal of Biological Chemistry, 1951, Vol. 193, pp. 265-275.

MATA T., MARTINS A. A. and CAETANO N. S. (2010), Microalgae for biodiesel production and other applications: A review. Renewable and Sustainable Energy Reviews, 2010, Vol. 14, pp. 217-232. http://dx.doi.org/10.1016/j.rser.2009.07.020

MELIS A. and HAPPE T. Hydrogen Production, Green Algae as a Source of Energy. Plant Physiology, 2001, Vol. 127, pp. 740-748. http://dx.doi.org/10.1104/pp.010498

MIAO X. and WU Q. High yield bio-oil production from fast pyrolysis by metabolic controlling of Chlorella protothecoides. Journal of Biotechnology, 2004, Vol. 110, pp. 85-93. http://dx.doi.org/10.1016/j.jbiotec.2004.01.013

NICHOLS H. W. and BOLD H. C. Trichsarcina polyinorpha gene. et sp. nov. Journal of Phycology, 1969, Vol. 1, pp. 34-38. http://dx.doi.org/10.1111/j.15298817.1965.tb04552.x

ODLARE M., NEHRENHEIM E., RIBE V., THORIN E., GAVARE M. and GRUBE M. Cultivation of algae with indigenous species - potentials for regional biofuel production. Applied Energy, 2011, Vol. 88, pp. 3280-5. http://dx.doi.org/10.1016/j.apenergy.2011.01.006

PÉREZ M. V. J., CASTILLO P. S., ROMERA O., MORENO D. F. and MARTÍNEZ C. P. Growth and nutrient removal in free and immobilized planktonic green algae isolated from pig manure. Enzyme and Microbial Technology, 2004, Vol. 34, pp. 392-8.. http://dx.doi.org/10.1016/j.enzmictec.2003.07.010

PICCOLO T. 2008. Aquatic biofuels. GlobeFishFIIU.

http://www.globefish.org/files/Aquaticbiofuels_638.pdf PIENKOS P. T. and DARZINS A. The promise and challenges of micro-algal derived biofuels. Biofuel Bioproducts and Biorefining, 2009, Vol. 3, pp. 431-440. http://dx.doi.org/10.1002/bbb.159

PIRT S. J., LEE Y. K., WALACH M. R. PIRT, M. W., BALYUZI H. H. and BAZIN M. J. A tubular bioreactor for photosynthetic production of biomass from carbon dioxide: design and performance. Journal of Chemical Technology and Biotechnology, 1983, Vol. 33B, pp. 35-58.

POKOO-AIKINS G., NADIM A., EI-HALWAGI M. M. and MAHALEC V. Design and analysis of biodiesel 
production from algae grown through carbon sequestration. Clean Technologies and Environment Policy, 2010, Vol. 12, pp. 239-254. http://dx.doi.org/10.1007/s10098-009-0215-6

POWELL E. E., MAPIOUR M. L., EVITTS R. W. and HILL G. A. Growth kinetics of Chlorella vulgaris and its use as a cathodic half cell. Bioresource Technology, 2009, Vol. 100, pp. 269-274. http://dx.doi.org/10.1016/j.biortech.2008.05.032

PULZ O. Valuable products from biotechnology of microalgae. Applied Microbiology and Biotechnology, 2004, Vol. 65, pp. 635-648. http://dx.doi.org/10.1007/s00253-004-1647-x

RAMANATHAN V. The greenhouse theory of climate change: a test by an inadvertent global experiment. Science, 1998, Vol. 240, pp. 293-299. http://dx.doi.org/10.1126/science.240.4850.293

RAO A. R., DAYANANDA C., SARADA R., SHAMALA T. R. and RAVISHANKAR G. A. Effect of salinity on growth of green alga Botryococcus braunii and its constituents. Bioresource Technology, 2007, Vol. 98, pp. 560-564. http://dx.doi.org/10.1016/j.biortech.2006.02.007

REITAN K. I., RAINUZZO J. R. and OLSEN Y. Effect of nutrient limitation on fatty acid and lipid content of marine microalgae. Journal of Phycology, 1994, Vol. 30, No. 6, pp. 972-979. http://dx.doi.org/10.1111/j.00223646.1994.00972.x

RODOLFI L., ZITTELLI G. C., BASSI N., PADOVANI G., BIONDI N., BONNI G. and MARIO R. T. (2009), Microalgae for oil: strain selection, induction of lipid synthesis and outdoor mass cultivation in a low-cost photobioreactor. Biotechnology Bioengineering, 2009, Vol. 102, pp. 100-112. http://dx.doi.org/10.1002/bit.22033

SANCHEZ S., MARTINEZ M. E. and ESPINOLA F. Biomass production and biochemical variability of the marine microalga Isochrysis galbana in relation to culture medium. Biochemical Engineering Journal, 2000, Vol. 6, pp. 13-8. http://dx.doi.org/10.1016/S1369-703X(00)000711

SCHENK P., THOMAS-HALL S., STEPHENS E., MARX U., MUSSGNUG J., POSTEN C., KRUSE O. and HANKAMER B. Second generation biofuels: high efficiency microalgae for biodiesel production. BioEnergy Research, 2008, Vol. 1, pp. 20-43. http://dx.doi.org/10.1007/s12155-008-9008-8

SCRAGG A. H., ILLMAN A. M., CARDE A., SHALES S. W. Growth of microalgae with increased calorific values in tubular bioreactor. Biomass and
Bioenergy, 2002, Vol. 23, pp. 67-73. http://dx.doi.org/10.1016/S0961-9534(02)00028-4

SCRAGG A. H., MORRISON J., SHALES S. W. The use of fuel containing Chlorella vulgaris in a diesel engine. Enzyme and Microbial Technology, 2003, Vol. 33, pp. 884889. http://dx.doi.org/10.1016/j.enzmictec.2003.01.001

SEARCHINGER T., HEIMLICH R., HOUGHTON R. A., DONG F., ELOBEID A., FABIOSA J., TOKGOZ S., HAYES D. and YU T. H. Use of US croplands for biofuels increases greenhouse gases through emissions from land use change. Science Express, 2008, Vol. 319, pp. 1238-1240. SHEN Y., YUAN W., PEI Z. and MAO E. Heterotrophic Culture of Chlorella protothecoides in Various Nitrogen Sources for Lipid Production. Applied Biochemistry and Biotechnology, 2010, Vol. 160, pp. 1674 1684. http://dx.doi.org/10.1007/s12010-009-8659-z

SHEEHAN J., DUNAHAY T., BENEMANN J., ROESSLER P. 1998. A look back at the U.S. Department of Energy's Aquatic Species Program: Biodiesel from Algae. Close-Out report. National Renewable Energy Lab, Department of Energy, Golden, Colorado, U.S.A. Report number NREL/TP-580-24190, dated July 1998

SINGH A., NIGAM P. S. and MURPHY J. D. Mechanism and challenges in commercialisation of algal biofuels. Bioresource Technology, 2011, Vol. 102, pp. 2634. http://dx.doi.org/10.1016/j.biortech.2010.06.057

SPOLAORE P., JOANNIS-CASSAN C., DURAN E. and ISAMBERT A. Commercial applications of microalgae. Journal of Biosciences Bioengineering, 2006, Vol. 101, pp. 87-96. http://dx.doi.org/10.1263/jbb.101.87

TEPE Y., NAZ M. and TURKMEN M. Utilization of Different Nitrogen Sources by Cultures of Scenedesmus acuminatus. Turkish Journal of Fishery and Aquatic Sciences, 2006, Vol. 6, pp. 123-127.

WALKAR D. A. Biofuels - for better or worse? Annals of Applied Biology, 2010, Vol. 156, pp. 319-327. http://dx.doi.org/10.1111/j.1744-7348.2010.00404.x

WIEBE R. and GADDY V. L. The solubility of carbon dioxide in water at various temperatures from 12 to $40^{\circ}$ and at pressures to 500 atmospheres- Critical Phenomena. Journal of American Chemical Society, 1940, Vol. 62, pp. 815-817. http://dx.doi.org/10.1021/ja01861a033

XIN L., HONG-YING H., KE G. and JIA Y. Growth and nutrient removal properties of a freshwater microalga Scenedesmus sp. LX1 under different kinds of nitrogen sources. Ecological Engineering, 2010, Vol. 36, pp. 379381. http://dx.doi.org/10.1016/j.ecoleng.2009.11.003 
M.Sc. Jayanta TALUKDAR - Department of Biotechnology, Gauhati University, PhD student.

Main research area: Microalgae Biotechnology, Microalgae Biofuels

Address: $\quad$ Gopinath Bordoloi Road, Guwahati

781014, Assam, INDIA

Tel.: $\quad$ 0091-9954395143

E-mail: $\quad$ jayantabiotech.gu@gmail.com
PhD (Dr) Bhabesh Chandra Goswami - Department of Chemistry, Gauhati University, Professor

Main research area: Carotenoids and Vitamins, Microalgae Biofuels

Address: Gopinath Bordoloi Road, Guwahati

Tel.: $\quad$ 781014, Assam, IND

E-mail: bcg2005@sify.com
PhD (Dr) Mohan Chandra Kalita - Department of Biotechnology, Gauhati University, Professor Main research area: Natural Resource Products, Plant Biotechnology, Microalgae Biofuels

Address: Gopinath Bordoloi Road, Guwahati

781014, Assam, INDIA

Tel.:

0091-9957181630

E-mail: mckalita@sify.com

\title{
Tirpių neorganinių anglies ir azoto junginių įtaka mikrodumblių Ankistrodesmus falcatus (Corda) Ralfs augimui, lipidụ ir energetinès vertès nustatymas, auginimo švariame vandenyje ir vandenyje su priedais palyginimas
}

\author{
Jayanta Talukdar ${ }^{1}$, Mohan Chandra Kalita ${ }^{1}$, Bhabesh Chandra Goswami ${ }^{2}$ \\ ${ }^{1}$ Biotechnologiju katedra, Gauhati univesitetas, Indija \\ ${ }^{2}$ Chemijos katedra, Gauhati univesitetas, Indija
}

(gauta 2012 m. kovo mén., priimta spaudai 2012 m. rugséjo mèn.)

Biologiniams degalams gaminti puikiai tinka švariame vandenyje augantys aliejiniai mikrodumbliai A. falcatus, kurie buvo anksčiau analizuoti dèl didelio lipidų kiekio juose. Siekiant nustatyti cheminę sudètị, $\mathrm{pH}$, azoto kiekị ( $\mu$ ), bendrą lipidų kiekị (TL) ir energetinę vertę $(\mathrm{CV})$, laboratorijoje buvo atlikti tyrimai su mikrodumbliais. Duomenys rodo, jog dumbliu, augintų laboratorijoje, rezultatai buvo geresni $(\mu=0,498 \mathrm{~d}-1$, TL $=43,4 \%$ ir $\mathrm{CV}=23,4 \mathrm{kJg}-1)$ nei dumbliu, augintu lauke $(\mu=0,385 \mathrm{~d}-1, \mathrm{TL}=38,2 \%$ ir $\mathrm{CV}=19,2 \mathrm{kJg}-1)$. Esant $\mathrm{pH}<7,0$ ir $>9,0$, buvo stipriai neigiamai paveiktos dumbliu kolonijos. Vidutinis $\mathrm{pH}(\approx 7,0)$ ir $\mathrm{NaHCO} 3$ koncentracija (30 mgL-1), šviesos intensyvumas $35 \mu \mathrm{mol}$ fotonų m-2s -1 , temperatūra $25 \pm 20 \mathrm{C}$ ir 16:8 h šviesos ir tamsos fotoperiodinis ciklas - optimalios sąlygos dumbliams augti. Vietoj NH4+ buvo naudojamas NO3- jonas, kuris gaunamas iš junginių, naudojamų atitinkamai pagal eilę $\mathrm{KNO} 3>\mathrm{NaNO} 3>\mathrm{NH} 4 \mathrm{NO} 3>(\mathrm{NH} 2) 2 \mathrm{CO}$, siekiant sukurti maksimalų biologinès masès ir lipidų koncentracijos prieaugi. Maksimalus biomasės kiekis, lipidų kiekis (TL) ir energetinè verte (CV) $(0,843 \mathrm{gL}-1,42,7 \%$ ir $20,6 \mathrm{kJg}-1$ atitinkamai) buvo nustatyta naudojant vidutinès koncentracijos KNO3 $(17,6 \mathrm{mM})$ tirpalą. Taip pat buvo nustatyta teigiama koreliacija tarp lipidų kiekio ir biologinès masės prieaugio $(\mathrm{R} 2=0,9461)$. Ivertinus šiuos argumentus ir padidinus biologinès masès bei lipidų prieaugị, būtų galima teigti, jog mikrodumbliai A. falcatus galètų būtų viena iš alternatyvų biologiniams degalams gaminti. 